\title{
Proceeding
}

Supplementary Issue: Spring Conferences of Sports Science. Costa Blanca Sports Science Events, 19-20 June 2020. Alicante, Spain.

\section{Intermittent training and improvement of anthropometric parameters and aerobic capacity in youth football}

\author{
ANTONIO CALANDRO , GIOVANNI ESPOSITO, GAETANO ALTAVILLA \\ Department of Human, Philosophical and Education Sciences, University of Salerno, Italy
}

\begin{abstract}
Optimal football training, among many targets, should allow both the improvement of the maximum oxygen intake $\left(\mathrm{VO}_{2 \mathrm{max}}\right)$, as well as the body mass index or BMI. The aim of this study is to demonstrate the effectiveness of the methodology of intermittent training, in terms of a significant improvement in the performance of the players involved in the study. The study is useful for trainers to reorganize training planning and adapt it to individual players. The method is experimental and involves the usual parameters for performance monitoring. There were 17 young amateur footballers, aged between 16 and 17, who participated in the regional under-17 championship this year. Data were collected over the course of twelve weeks. They were expressed as average \pm SD for: height (176.1 \pm 8.45$)$, weight $(63.3 \pm 12.7)$ and body mass index $(20.2 \pm 2.5)$. Gacon intermittent field test was used to determine the $\mathrm{VO}_{2 \text { max. }}$ Statistical data analysis was performed with the t-test to check the differences between pre-test and post-test (at the beginning and end of three months of specific training). Significant differences were fixed at $p<.05$. Results show that there is a significant difference in performance between pre and post-workout for tests conducted. Keywords: Intermittent training; Gacon test; $\mathrm{BMl} ; \mathrm{VO}_{2 \max }$.

Cite this article as:

Calandro, A., Esposito, G., \& Altavilla, G. (2020). Intermittent training and improvement of anthropometric parameters and aerobic capacity in youth football. Journal of Human Sport and Exercise, 15(3proc), S599S608. doi:https://doi.org/10.14198/ihse.2020.15.Proc3.12
\end{abstract}

\footnotetext{
Corresponding author. Department of Human, Philosophical and Education Sciences, University of Salerno, Italy.

E-mail: a.calandro1@studenti.it

Supplementary Issue: Spring Conferences of Sports Science. Costa Blanca Sports Science Events, 19-20 June 2020. Alicante, Spain.

JOURNAL OF HUMAN SPORT \& EXERCISE ISSN 1988-5202

(c) Faculty of Education. University of Alicante

doi:10.14198/jhse.2020.15.Proc3.12
} 


\section{INTRODUCTION}

Each type of physical activity always brings about changes in the body. Through systematic and continuous repetition, training determines physiological effects with consequent functional responses that promote an improvement in performance (Izzo et al., 2020ab) and in several cases could be dangerous for the health and performance for the damage (Sannicandro et al, 2017, 2016, 2015ab, 2014, 2012ab, 2011ab, 20210, 2008). Relevant to improve the performance is the definition of Verkhoshansky about training as "process by which it is possible to bring out the maximum, or in any case, the highest percentage of an athlete's genetic potential". In fact, depending on whether they are amateur, competitive, or high-level athletes, training always brings changes and adaptations to the body (Izzo et al., 2019abc). These changes can be of various types: anatomical (such as the increase in muscle volume or heart size); ultrastructural (such as increasing the number of mitochondria, or transforming muscle fibres from one type to another); biochemicals (linked to enzymatic changes); and exclusively functional changes (where what changes is the function). In the specific case of intermittent work, it is a method that allows to train different motor qualities simultaneously such as endurance and strength and, it is characterized by an alternation of maximum effort and recovery carried out actively (Gaetano \& Rago, 2014). It is carried out with the aim of achieving and reconciling two different objectives: stimulating the aerobic system (raising the level of maximum aerobic power) and improving the propulsive force in particular that of support (Rago et al., 2017). In this way, every study on related study could have the basis to deep the issue (Sgrò et al, 2018, 2017ab, 2016, 2015, 2009) as well as the interdisciplinary investigations on the other sport or physical activity, because it is relevant for this specific aspects of training methods (Invernizzi et al, 2020, 2014ab, 2008). The origins of intermittent football work go back to research by the Swedish physiologist Per-Olof Åstrand. The ability to perform intermittent and high intensity exercises for prolonged periods today plays a key role in competitive football (Federici et al., 2019). As a result, training and testing strategies have been proposed to monitor and improve players' ability to perform high-intensity activities during the match (Raiola \& Altavilla, 2020). Although talent selection is an uncertain procedure because there are many different factors that are involved in the development of a potential player, knowledge of player profiles has been shown as a valuable resource to guide talent selection and subsequent coaching (Esposito et al., 2020). In addition, the evaluation of changes induced by different training strategies on physical components relevant to football's performance is important in the control of the training process (Raiola \& D'Isanto, 2016; Coppola \& Raiola, 2019).) Therefore, the identification of valid field tests that allow the assessment of the specific resistance of football in young players is of fundamental importance (Ceruso et al., 2019).

\section{Aim of the study}

The aim of this study is to demonstrate the effectiveness of the intermittent training methodology, carried out over a period of 12 weeks, in relation to an improvement in the $\mathrm{VO}_{2 \max }$ value and the $\mathrm{BMI}$ of the athletes involved.

\section{MATERIAL AND METHODS}

\section{Subject}

Seventeen young amateur footballers from the club Grippo DRS, aged between 16 and 17, who took part in the regional under-17 championship were observed. To be included in the study, athletes had to be injuryfree and not have sustained any training suspension during the previous six months. All players were familiar with the use of intermittent training methodology. The research design and procedures comply with the standards set out in the Helsinki declaration. 


\section{Procedures}

In a first phase of the study, before the intermittent training period, the anthropometric values of each boy were obtained. Specifically: weight and height from which the BMl or body mass index was then obtained. The collected data were reported in a table, calculating the average and the standard deviation, to establish normality criteria within the group. The BMI data is considered as a generic index of the player's physical form and is very useful because it allows to classify players into categories. In young people the BMI shows a considerable variability mainly linked to age and gender, so for this parameter in Italy are used the percentiles proposed by Cacciari et al. in 2006. At international level there are the reference parameters proposed by Cole et al., (2005) which indicate as underweight a BMI lower than the 5th percentile, normal between the 5th and the 85th percentile, at an overweight risk between the 85th and the 95th percentile and obese beyond the 95th percentile.

Table 1. BMI Reference Parameters (Cole et al., 2000).

\begin{tabular}{ll}
\hline Classification & Percentiles \\
\hline Underweight & $<5$ \\
Normal weight & 5 and $<85$ \\
Overweight & 85 and $<95$ \\
Obese & 95 \\
\hline
\end{tabular}

This parameter allows to intervene by educating players on the concepts of health and fitness, with important preventive effects. Higher values seem to negatively affect technical-tactical performance since the masses to be accelerated and decelerate in the changes of direction seem to be excessive. After the detection of the anthropometric characteristics, the players were subjected to the Gacon test in order to obtain the V02max. The test involves an alternation of stroke sections lasting $45 \mathrm{~s}$, with recovery moments of $15 \mathrm{~s}$. The initial speed is $10 \mathrm{~km} / \mathrm{h}$ which corresponds to a stretch of $125 \mathrm{~m}$ (covered in $45 \mathrm{~s}$ ). After a pause of $15 \mathrm{~s}, 6.25 \mathrm{~m}$ more is covered (total $131.25 \mathrm{~m}$, equal to $10.5 \mathrm{~km} / \mathrm{h}$ ) and so on until the athlete can no longer cover the expected distance in $45 \mathrm{~s}$. This test is a maximal test which foresees accelerations and decelerations and short breaks between the different loads (Roi, 2014). It does not foresee changes of the running direction. It needs a perfectly calibrated sound system. Provides an underestimation of the VAM compared to non-shuttle tests. The figure shows the original scheme for the Gacon test.

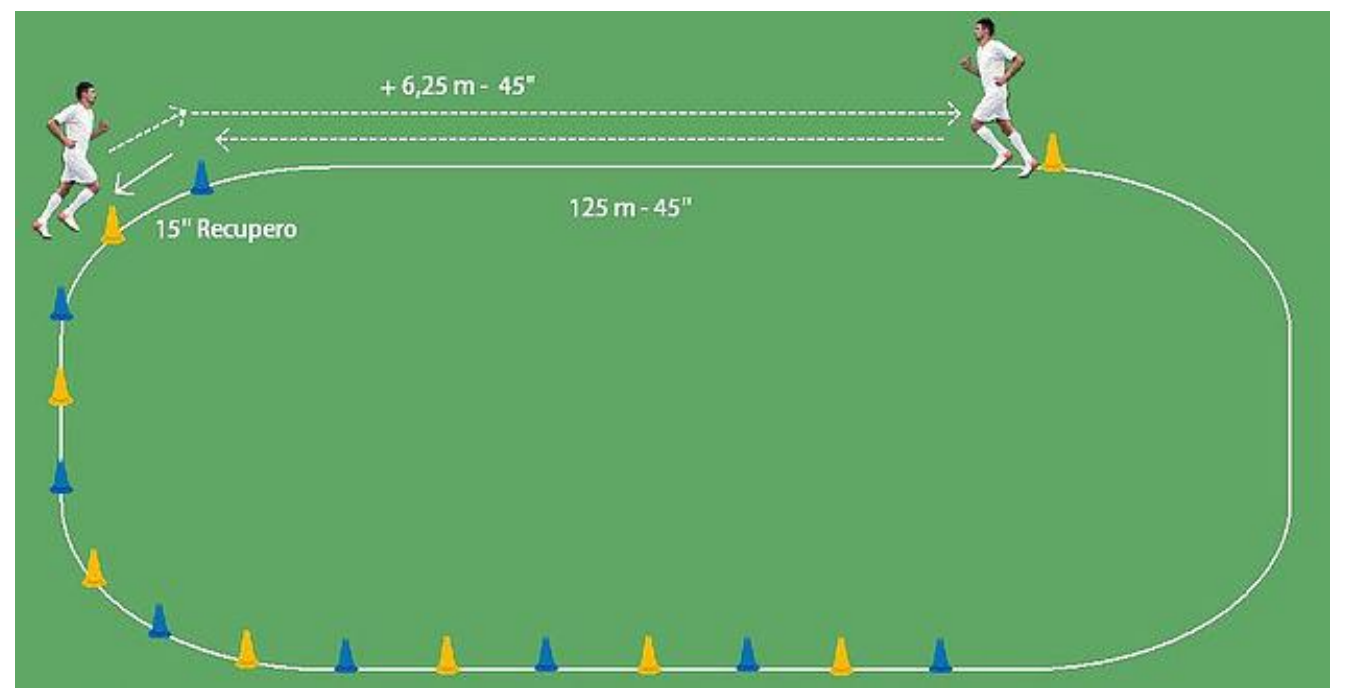

Figure 1. Gacon Test Scheme. 
The test was repeated after three months. In the period between the two tests, the workouts were structured by repeating intermittent training twice a week in the preparation phase, and once a week during competition phase. After an initial phase of activation, intermittent training was carried out, following this pattern:

Table 2. Intermittent training scheme used in the study.

\begin{tabular}{lccccc}
\hline & Workouts/week & Sprints/week & Sprint duration & Rest duration & Rest intensity \\
\hline Week 1 & 2 & 4 & $10 \mathrm{~s}$ & $10 \mathrm{~s}$ & 1 \\
Week 2 & 2 & 6 & $10 \mathrm{~s}$ & $10 \mathrm{~s}$ & 1 \\
Week 3 & 2 & 8 & $10 \mathrm{~s}$ & $10 \mathrm{~s}$ & 1 \\
Week 4 & 2 & 4 & $20 \mathrm{~s}$ & $20 \mathrm{~s}$ & 1 \\
Week 5 & 2 & 6 & $20 \mathrm{~s}$ & $20 \mathrm{~s}$ & 1 \\
Week 6 & 2 & 8 & $20 \mathrm{~s}$ & $20 \mathrm{~s}$ & 1 \\
Week 7 & 2 & 4 & $30 \mathrm{~s}$ & $30 \mathrm{~s}$ & 1 \\
Week 8 & 2 & 4 & $30 \mathrm{~s}$ & $30 \mathrm{~s}$ & 1 \\
Week 9 & 2 & 4 & $30 \mathrm{~s}$ & $30 \mathrm{~s}$ & $0-1$ \\
Week 10 & 3 & 4 & $30 \mathrm{~s}$ & $30 \mathrm{~s}$ & $0-1$ \\
Week 11 & 3 & 4 & $30 \mathrm{~s}$ & $30 \mathrm{~s}$ & $0-1$ \\
Week 12 & 3 & 4 & $30 \mathrm{~s}$ & $30 \mathrm{~s}$ & $0-1$
\end{tabular}

The alternation of 30 seconds of effort followed by 30 seconds of recovery was performed without interruption, with a circuit technique, for a total training time that could vary from 9 to 15 minutes overall. In this way, the cardiovascular system and the aerobic system of the athlete are stimulated. In fact, throughout the exercise time the heart rate remains at fairly high levels in a narrow range that goes from 160 to 180 beats per minute.

\section{Statistical analysis}

The results are presented as mean \pm standard deviation $(M \pm S D)$. The statistical model used is the paired sample t-test: tests to assess the significance of the differences between the averages of two samples that are related to each other, as well as when some subjects are evaluated on two different occasions. The results were presented as a number expressed as a percentage. Statistical analyses were performed using the Statistical Package for Social Sciences (SPSS 15.0 for Windows) software and the significance level was set at $p<.05$.

\section{RESULTS}

Table 3. Anthropometric characteristics of the subjects before training.

\begin{tabular}{lccccc}
\hline Players & Age & Weight & Height & BMI & Percentiles \\
\hline Player 1 & 17 & 67.2 & 183 & 20.1 & 38.6 \\
Player 2 & 17 & 82 & 190 & 22.7 & 69.5 \\
Player 3 & 16 & 50.2 & 170 & 17.4 & 9.5 \\
Player 4 & 17 & 63.5 & 171 & 21.7 & 59.9 \\
Player 5 & 16 & 57.3 & 177 & 18.3 & 19.8 \\
Player 6 & 16 & 55.9 & 172 & 18.9 & 28.1 \\
Player 7 & 16 & 46.8 & 160 & 18.3 & 19.8 \\
Player 8 & 16 & 86 & 185 & 25.1 & 86.9 \\
Player 9 & 16 & 48.6 & 160 & 19 & 29.5 \\
Player 10 & 16 & 63.3 & 181 & 19.3 & 34.1 \\
Player 11 & 16 & 68.5 & 177 & 21.9 & 66.3 \\
\hline
\end{tabular}




\begin{tabular}{lccccc}
\hline Player 12 & 16 & 69.2 & 177 & 22 & 67.7 \\
Player 13 & 17 & 59.5 & 169 & 20.08 & 49.2 \\
Player 14 & 17 & 82 & 186 & 23.7 & 77 \\
Player 15 & 17 & 60 & 180 & 18.5 & 17.4 \\
Player 16 & 17 & 66.5 & 182 & 20.1 & 38.6 \\
Player 17 & 17 & 68.5 & 175 & 22.4 & 66.3 \\
Mean & 16.4 & 64.4 & 176.1 & 20.5 & 45.7 \\
SD & 0.51 & 11.4 & 8.4 & 2.1 & 23.7 \\
\hline
\end{tabular}

Table 4. Gacon test results before the training period.

\begin{tabular}{lccc}
\hline Players & Fraction Speed & Fraction Distance $(\mathbf{m})$ & VO $_{2 \max }$ \\
\hline Player 1 & 16 & 200 & 48 \\
Player 2 & 16 & 200 & 48 \\
Player 3 & 16 & 200 & 48 \\
Player 4 & 17.5 & 218 & 53 \\
Player 5 & 17.5 & 218 & 53 \\
Player 6 & 16 & 200 & 48 \\
Player 7 & 18.5 & 231 & 56 \\
Player 8 & 17.5 & 218 & 53 \\
Player 9 & 17.5 & 218 & 53 \\
Player 10 & 17 & 212 & 51 \\
Player 11 11 & 212 & 51 \\
Player 12 & 17 & 218 & 53 \\
Player 13 & 17.5 & 200 & 48 \\
Player 14 & 16 & 200 & 48 \\
Player 15 & 16 & 212 & 51 \\
Player 16 & 17 & 218 & 53 \\
Player 17 & 17.5 & 212 & 51 \\
Mean & 17 & 211 & 50.9 \\
SD & 16.9 & 9.43 & 2.53 \\
\hline
\end{tabular}

Table 5. Anthropometric characteristics of subjects after training period.

\begin{tabular}{lccccc}
\hline Players & Age & Weight & Height & BMI & Percentiles \\
\hline Player 1 & 17 & 67.3 & 183 & 20.1 & 33 \\
Player 2 & 17 & 86 & 190 & 23.8 & 78 \\
Player 3 & 16 & 47.8 & 170 & 16.5 & 2 \\
Player 4 & 17 & 61.5 & 171 & 21 & 47 \\
Player 5 & 16 & 56.3 & 177 & 18 & 12 \\
Player 6 & 16 & 52.9 & 172 & 17.9 & 11 \\
Player 7 & 16 & 44.8 & 160 & 17.5 & 8 \\
Player 8 & 16 & 88 & 185 & 25.7 & 91 \\
Player 9 & 16 & 45.6 & 160 & 17.8 & 11 \\
Player 10 & 16 & 62.3 & 181 & 19 & 26 \\
Player 11 & 16 & 66.5 & 177 & 21.2 & 59 \\
Player 12 & 16 & 68.2 & 177 & 21.8 & 66 \\
Player 13 & 17 & 57.5 & 169 & 20.1 & 34 \\
Player 14 & 17 & 80 & 186 & 23.1 & 72 \\
\hline & & & & VOLUME 15|Proc3| 2020| S603
\end{tabular}




\begin{tabular}{lccccc}
\hline Player 15 & 17 & 59 & 180 & 18.2 & 9 \\
Player 16 & 17 & 66.5 & 182 & 20.1 & 33 \\
Player 17 & 17 & 66.5 & 175 & 21.7 & 56 \\
Mean & 16.4 & 63.3 & 176.1 & 20.2 & 38.11 \\
SD & 0.51 & 12.7 & 8.45 & 2.5 & 28.03 \\
\hline
\end{tabular}

Table 6. Gacon test results after the training period.

\begin{tabular}{lccc}
\hline Players & Fraction Speed & Fraction Distance $(\mathbf{m})$ & $\mathbf{V O}_{2 \max }$ \\
\hline Player 1 & 16.5 & 206 & 50 \\
Player 2 & 17 & 212 & 51 \\
Player 3 & 19 & 237 & 57 \\
Player 4 & 19.5 & 243 & 59 \\
Player 5 & 18.5 & 231 & 56 \\
Player 6 & 18 & 225 & 54 \\
Player 7 & 19.5 & 243 & 59 \\
Player 8 & 18 & 225 & 54 \\
Player 9 & 19.5 & 243 & 59 \\
Player 10 & 19.5 & 243 & 59 \\
Player 11 & 19.5 & 243 & 59 \\
Player 12 & 19.5 & 243 & 59 \\
Player 13 & 17.5 & 218 & 53 \\
Player 14 & 16 & 200 & 48 \\
Player 15 & 17.5 & 218 & 53 \\
Player 16 & 19 & 237 & 57 \\
Player 17 & 19.5 & 243 & 59 \\
Mean & 18.44 & 230 & 55.64 \\
SD & 1.18 & 14.6 & 3.65 \\
\hline
\end{tabular}

Table 7. Application of the paired sample t-test.

\begin{tabular}{lll}
\hline & $V_{2 \text { MAX }}$ & $V_{2 \text { MAX }}(2)$ \\
\hline Mean & 50.94117647 & 55.64705882 \\
Variance & 6.433823529 & 13.36764706 \\
Observations & 17 & 17 \\
Overall Variance & 9.900735294 & \\
$\mathrm{df}$ & 32 & \\
$\mathrm{t}$ stat & -4.360304346 & \\
$\mathrm{p}(\mathrm{T}<=\mathrm{t})$ one-tail & $6.3014 \mathrm{E}-05$ & \\
$\mathrm{t}$ Critical one-tail & 1.693888748 & \\
$\mathrm{p}(\mathrm{T}<=\mathrm{t})$ two-tail & 0.000126028 & \\
$\mathrm{t}$ Critical due code & 2.036933343 & \\
\hline
\end{tabular}

\section{DISCUSSION}

By using the t-test it is possible to accept the null hypothesis as the significant improvement margin due to the applied methodology has been confirmed, consequently rejecting the alternative hypothesis. As can be seen from the results, in the comparison of pre and post training $\mathrm{VO}_{2 \mathrm{Max}}$, a statistically significant result emerges, consequently interval training has allowed to improve the results in terms of $\mathrm{VO}_{2 \mathrm{Max}}$. It is also 
possible to observe a significant improvement in the body mass index following the three months of training as shown in table 3. In the detection of the anthropometric characteristics both pre and post training, only one player is overweight while all the others fall within the normal weight range. The results of this study regarding the effectiveness of interval training in youth football are consistent with those of other studies including those by Faude et al., (2014) and Cvetković, N., et al., (2018). In the first study cited, the authors showed that four weeks of in-season endurance training can lead to significant improvements in stamina. Significant effects were observed in the individual anaerobic threshold $(+1.3 \%, \eta \mathrm{p} 2=.31)$, in the peak heart rate $(-1.8 \%, \eta \mathrm{p} 2=.45)$ and $\mathrm{CMJ}(-2.3 \%, \mathrm{\eta p} 2=.27)$, without any interaction significant among the groups $(\mathrm{p}$ $>$.30). In the second study, however, the authors concluded that intermittent training allowed significant improvements in multiple muscle and cardiorespiratory measures after 12 weeks of training in overweight and obese male children. In contrast, the control group, which only performed physical education lessons, showed small changes over the 12-week course with a significant increase in body mass, BMI, and fat mass values. Finally, in the study by Rago et al., (2017) the collected data submitted to a statistical study showed improvements in the physical performance of the different athletes thanks to the use of the periodization method integrated in the intermittent high intensity training. According to the periodization method, the gradual increase in the applied load that allows the central nervous system (CNS) to adapt and obtain improvements is significant. In conclusion, the advantage and originality of intermittent training is to allow muscles to function in a lasting, high aerobic regime by limiting the formation of lactic acid to a minimum and thus avoiding muscle pain or soreness (Izzo et al., 2019). Another important advantage of this training method is from a physiological point of view: there is an increase in the functionality of myoglobin, which is a muscle protein used for the transport of oxygen at the intramuscular level (Helgerud et al., 2001). In the joint Resistance-Strength training there is an alternation at the muscular level of involvement of the fast, easily fatigued fibres, and of the resistant fibres during the recovery period.

\section{CONCLUSION}

The results and discussion show that athletes' performance has significantly improved thanks to a specific twelve-week workout. Intermittent training for the sample taken into consideration was useful and brought about an improvement in $\mathrm{BMI}$ as well as in $\mathrm{VO}_{2 \max }$. The initial hypothesis was therefore confirmed through the statistical study. Intermittent work is therefore a training method that can be applied without problems even on young athletes since it minimizes the formation of lactic acid and the onset of injuries. This study also demonstrated the importance of paying attention to the recovery phase, which in this method is of equal if not greater importance than the effort. It must never be higher than 30 s in order not to allow the heart rate to drop too low.

\section{REFERENCES}

Cacciari, E., Milani, S., Balsamo, A., Spada, E., Bona, G., Cavallo, L., ... \& Cicognani, A. (2006). Italian cross-sectional growth charts for height, weight and BMI (2 to $20 \mathrm{yr}$ ). Journal of endocrinological investigation, 29(7), 581-593. https://doi.org/10.1007/bf03344156

Ceruso, R., Esposito, G., \& D'Elia, F. (2019). Analysis and evaluation of the qualitative aspects of the young players. Journal of Physical Education and Sport, 19, 1814-1819.

Cole, T. J., Faith, M. S., Pietrobelli, A., \& Heo, M. (2005). What is the best measure of adiposity change in growing children: BMI, BMI\%, BMl z-score or BMI centile?. European journal of clinical nutrition, 59(3), 419-425. https://doi.org/10.1038/si.ejcn.1602090

Coppola, C., Raiola, G. (2019). Interest in VO2 max capacity: Comparing Norwegian and Italian training, Journal of Physical Education and Sport, 19, art. no. 268, pp. 1825-1827. 
Cvetković, N., Stojanović, E., Stojiljković, N., Nikolić, D., Scanlan, A. T., \& Milanović, Z. (2018). Exercise training in overweight and obese children: Recreational football and high-intensity interval training provide similar benefits to physical fitness. Scandinavian journal of medicine \& science in sports, 28 , 18-32. https://doi.org/10.1111/sms.13241

Esposito, G., Altavilla, G., \& D'Elia, F. A method for identifying talent in youth football through the use of evaluation tests. Sport Science 13 (2020) 1: 119-126.

Faude, O., Steffen, A., Kellmann, M., \& Meyer, T. (2014). The effect of short-term interval training during the competitive season on physical fitness and signs of fatigue: A crossover trial in high-level youth football players. International journal of sports physiology and performance, 9(6), 936-944. https://doi.org/10.1123/ijspp.2013-0429

Federici, A., Zumbo, F., Raiola, G. (2019). Use of chains as a means of intensifying the load in resistance training, Journal of Physical Education and Sport, 19, art. no. 68, pp. 466-472.

Francini, L., Rampinini, E., Bosio, A., Connolly, D., Carlomagno, D., \& Castagna, C. (2019). Association Between Match Activity, Endurance Levels and Maturity in Youth Football Players. International journal of sports medicine, 40(09), 576-584. https://doi.org/10.1055/a-0938-5431

Gaetano, R., \& Rago, V. (2014). Preliminary study on effects of hiit-high intensity intermittent training in youth soccer players. Journal of Physical Education \& Sport, 14(2).

Helgerud, J., Engen, L. C., Wisloff, U., \& Hoff, J. (2001). Aerobic endurance training improves soccer performance. Medicine and science in sports and exercise, 33(11), 1925-1931. https://doi.org/10.1097/00005768-200111000-00019

Invernizzi, P.L., Signorini, G., Bosio, A., Raiola, G., Scurati, R. (2020) Validity and reliability of selfperception-based submaximal fitness tests in young adult females: An educational perspective Sustainability, 12 (6). https://doi.org/10.3390/su12062265

Invernizzi, P.L., Limonta, E., Bosio, A., Scurati, R., Veicsteinas, A., Esposito, F. (2014a) Effects of a 25$\mathrm{km}$ trial on psychological, physiological and stroke characteristics of short- And mid-distance swimmers Journal of Sports Medicine and Physical Fitness, 54 (1), pp. 53-62.

Invernizzi, P.L., Longo, S., Scurati, R., Maggioni, M.A., Michielon, G., Bosio, A. (2014b) Interpretation and perception of slow, moderate, and fast swimming paces in distance and sprint swimmers Perceptual and Motor Skills, 118 (3), pp. 833-849. https://doi.org/10.2466/27.29.pms.118k23w0

Invernizzi, P.L., Longo, S., Scurati, R. (2008) Analysis of heart rate and lactate concentrations during coordinative tasks: Pilot study in karate kata world champions Sport Sciences for Health, 3 (1-2), pp. 41-46. https://doi.org/10.1007/s11332-008-0053-7

Izzo, R., Raiola, G., D'isanto, T., Cejudo, A., Giovanelli, G.M. (2020a)Modelling an adequate profile for a more targeted work methodology, with dedicated technologies, for elite-level footballers: Comparison between sub 17 vs sub 19, highlights and shadows, Sport Science, 13 (1), pp. 36-42.

Izzo, R., D'isanto, T., Raiola, G., Cejudo, A., Ponsano, N., Varde'i, C.H. (2020b) The role of fatigue in football matches, performance model analysis and evaluation during quarters using live global positioning system technology at 50hz, Sport Science, 13 (1), pp. 30-35.

Izzo, R., Giovannelli, M., Raiola, G. (2019a)Training load in elite goalkeepers with k-track for monitoring performance, Journal of Physical Education and Sport, 19, art. no. 280, pp. 1890-1896.

Izzo, R., Giovannelli, M., D'isanto, T. (2019b) The injury prevention program WTA functional primitive movement in professional football players: A case study Journal of Physical Education and Sport, 19 , art. no. 279, pp. 1885-1889.

Izzo, R., Giovannelli, M., D'isanto, T. The injury prevention program WTA functional primitive movement in professional football players: A case study (2019c) Journal of Physical Education and Sport, 19, art. no. 279 , pp. 1885-1889. 
Raiola, G., D'isanto, T. (2016). Assessment of periodization training in soccer. Journal of Human Sport and Exercise, 11 (Proc1), pp. S267-S278. https://doi.org/10.14198/jhse.2016.11.proc1.19

Raiola, G., \& Altavilla, G. (2020). Testing motor skills, general and special coordinative, in young soccer. Journal of Human Sport and Exercise, 15(2proc), S206-S212. https://doi.org/10.14198/jhse.2020.15.proc2.11

Rago, V., Pizzuto, F., Raiola, G. (2017). Relationship between intermittent endurance capacity and match performance according to the playing position in sub-19 professional male football players: Preliminary results, Journal of Physical Education and Sport, 17 (2), art. no. 103, pp. 688-691.

Rago, V., Pizzuto, F., \& Raiola, G. (2017). Relationship between intermittent endurance capacity and match performance according to the playing position in sub-19 professional male football players: Preliminary results. Journal of physical education and sport, 17(2), 688.

Roi, Giulio S. "I test di valutazione funzionale nel calcio." Edizioni Correre 37 (2014).

Sannicandro, I. (2017) Effects of strength and core stability training versus strength and aerobic training in subjects aged over 65 [Article@Effetti dell'allenamento di forza e core stability versus allenamento di forza e aerobico a intensità controllata in soggetti over 65] Medicina dello Sport, 70 (4), pp. 410418.

Sannicandro, I., Cofano, G., Rosa, A.R. (2016) Heart rate response comparison of young soccer plyers in "cage" small-sided and 8vs8 games Journal of Physical Education and Sport, 16 (4), art. no. 180, pp. 1122-1127.

Sannicandro, I., Spedicato, M., Palaia, G., Cofano, G., Bisciotti, G.N., Eirale, C. (2015a) Strength ability, endurance and anthropometric parameters in youth football: Descriptive analysis and functional relationships [Article@Capacità di forza, endurance e parametri antropometrici nel calcio giovanile: Analisi descrittiva e rapporti funzionali] Medicina dello Sport, 68 (1), pp. 19-30.

Sannicandro, I., Piccinino, A., Cofano, G., Eirale, C., Biscotti, G.N. (2014) Effects of plyometric training on phases of jumping in young fencers [Article@Effetti dell'allenamento pliometrico sulle fasi del salto in giovani schermidori] Medicina dello Sport, 67 (1), pp. 27-45.

Sannicandro, I., Piccinno, A., Cofano, G., De Pascalis, S., Rosa, A.R. (2012a) Analysis of some variable performances of under 12 tennis players [Article@Analisi di alcune variabili prestative del giovane tennista under 12] Medicina dello Sport, 65 (4), pp. 473-484.

Sannicandro, I., Rosa, R.A., De Pascalis, S., Piccinno, A. (2012b) The determination of functional asymmetries in the lower limbs of young soccer players using the countermovement jump. The lower limbs asymmetry of young soccer players Science and Sports, 27 (6), pp. 375-377. https://doi.org/10.1016/j.scispo.2011.11.001

Sannicandro, I. Evaluation of muscle strength in young and top-level soccer players (2011a) [Article@La valutazione delia capacità di forza nel giovane calciatore e nel top level] Medicina dello Sport, 64 (1), pp. 9-20.

Sannicandro, I., Piccinno, A., Cataleta, R., Maffione, E., De Pascalis, S. (2010) The fencing lunee: Analysis of load distribution to the lower limbs and gender-related differences in young fencers in relation to accident prevention [Article@L'affondo nella scherma giovanile: Analisi del carico imposto ai due arti inferiori e differenze di genere per la prevenzione degli infortuni] Medicina dello Sport, 63 (3), pp. 353-364.

Sannicandro, I., Colella, D., Rosa, R.A., Manno, R. (2008) Modulation of motor load in old people: Effect of different exercise training protocols on power flexibility [Article@La modulazione del carico motorio in età avanzata: Effetti di differenti protocolli di training sui valori di forza, flessibilità ed endurance] Medicina dello Sport, 61 (4), pp. 443-454. 
Sgrò, F., Pignato, S., Lipoma, M. (2018) Assessing the impact of gender and sport practice on students 'performance required in team games Journal of Physical Education and Sport, 18, art. no. 71, pp. 497-502.

Sgrò, F., Quinto, A., Messana, L., Pignato, S., Lipoma, M. (2017a) Assessment of gross motor developmental level in italian primary school children Journal of Physical Education and Sport, 17 (3), art. no. 192, pp. 1954-1959.

Sgrò, F., Mango, P., Pignato, S., Schembri, R., Licari, D., Lipoma, M. (2017b) Assessing Standing Long Jump Developmental Levels Using an Inertial Measurement Unit Perceptual and Motor Skills, 124 (1), pp. 21-38. https://doi.org/10.1177/0031512516682649

Sgro', F., Quinto, A., Pignato, S., Lipoma, M. (2016) Comparison of product and process oriented model accuracy for assessing countermovement vertical jump motor proficiency in pre-adolescents Journal of Physical Education and Sport, 16 (3), art. no. 145, pp. 921-926.

Sgrò, F., Licari, D., Coppola, R., Lipoma, M. (2015)Assessment of balance abilities in elderly people by means of a clinical test and a low-cost force plate Kinesiology, 47 (1), pp. 33-43.

Sgrò, F., Lo Bello, L., Lipoma, M. A networked embedded computing platform for physical activity assessment (2009) Proceedings - 2009 2nd Conference on Human System Interactions, HSI '09, art. no. 5090970, pp. 146-151. https://doi.org/10.1109/hsi.2009.5090970

\section{@(@) $\Theta \Theta$}

This work is licensed under a Attribution-NonCommercial-NoDerivatives 4.0 International (CC BY-NC-ND 4.0). 